\title{
CRUSADING AND MATRIMONY IN THE DYNASTIC POLICIES OF MONTFERRAT AND SAVOY
}

\author{
JOHN W. BARKER \\ UNIVERSITY OF WISCONSIN-MADISON. U.S.A.
}

\begin{abstract}
The uses of matrimony have always been standard practices for dynastic advancement through the ages. A perfect case study involves two important Italian families whose machinations had local implications and widespread international extensions. Their competitions are given particular point by the fact that one of the two families, the House of Savoy, was destined to become the dynasty around which the Modern State of Italy was created.

This essay is, in part, a study in dynastic genealogies. But it is also a reminder of the wide impact of the crusading movements, beyond military operations and the creation of ephemeral Latin States in the Holy Land.
\end{abstract}

Keywords: Matrimony, Crusading, Montferrat, Savoy, Levant.

\section{CRUZADA Y MATRIMONIO EN LAS POLÍTICAS DINÁSTICAS DE MONTFERRATO Y SABOYA}

Resumen: Los usos del matrimonio siempre han sido las prácticas estándar de ascenso dinástico a través de los tiempos. Un caso de estudio perfecto implica a dos importantes familias italianas cuyas maquinaciones tenían implicaciones locales y extensiones internacionales generalizadas. Sus competencias tienen como punto particular el hecho de que una de las dos familias, la Casa de Saboya, estaba destinada a convertirse en la dinastía alrededor de la cual se creó el Estado Moderno de Italia.

Este ensayo es, en parte, un estudio sobre genealogía dinástica. Pero también es un recordatorio de la gran repercusión de los movimientos cruzados, más allá de las operaciones militares y la creación de efímeros Estados Latinos en la Tierra Santa.

Palabras clave: Matrimonio, Cruzada, Montferrato, Saboya, Levante.

Recibido: 25.01.2016 - Aceptado: 11.04.2016

Correspondencia: John W. Barker

Email: jwbarker@wisc.edu

Professor Emeritus of History- University of Wisconsin-Madison 


\section{CRUSADING AND MATRIMONY IN THE EASTERN MEDITERRANEAN: THE DYNASTIC POLICIES OF MONTFERRAT AND SAVOY ${ }^{1}$}

he use of matrimonial alliances by monarchs and princes is
as old as royalty itself. The pursuit of foreign adventurism
for dynastic advancement is probably about as old. These two dynastic strategies are familiar features in the annals of both Byzantium and the Crusades. Indeed, the world of crusading itself generated new interactions of the two.

Such phenomena are usually studied in their Levantine context rather than in terms of the participants themselves and their varying home contexts. Reversing that approach can offer fresh perspectives, especially when considering dynasties with a continuity of involvement. There can be few better cases in point than the parallel dynastic houses of Montferrat and Savoy. Their territories were contiguous, their situations were sometimes competitive, but their policies were almost in counterpoint with each other. Representing regional principalities of their type, these two houses found in crusading and matrimony mechanisms that might extend their influence and prestige far beyond local realities. Many segments of their Levantine involvements are well-known as individual episodes, but they form a more coherent picture when surveyed in totality ${ }^{2}$.

1 An early version of this essay was presented at the Sixth International Conference of the Society for the Study of the Crusades and the Latin East, in August 2004 at Istanbul. It has gone through much modification since then. I would like to thank David Jacoby, among others, for useful bibliographical advice given me in the course of my explorations of this topic, and Galo Garcés Ávalos, for his generous help in facilitating this publication.

2 The most comprehensive treatment of both these houses is Haberstumpf (1995), which includes cursory surveys of the Levantine activities of each house (pp. 19-29 for Montferrat; pp. 191-203 for Savoy), followed by series of detailed but unintegrated essays on specific topics and personalities. An older study of just one of these two dynasties is Usseglio (1926): the first volume tracing the background of the Aleramici in their Italian context through the era of Frederick Barbarossa, the second tracing the Montferrats' crusading and Levantine ventures. On one of the most important of the Aleramic Marquises, there is the pioneering if somewhat dated monograph by Ilgen (1880), then trans. by G. Cerrato in Ilgen (1890), with a further text and chronology by C. Cipolla. There is supposed to be a volume, I Monferrato in Terra Santa, published by one Roberto Maestri in 2001, but I have been unable to trace or secure this.

On the Ubertinidi, the only specialized study is Previté Orton (1912), which breaks off before the episodes of crusading and Byzantine contacts. 
In territorial terms, the Marquisate of Montferrat comprehended the western ends of Lombardy. The County of Savoy, located in the sub-Alpine Piedmont, a remnant of the old Burgundian Kingdom of Arles, was as much a part of what has become France as it was part of what has become Italy. The respective dynasties that assumed the rule of these regions each descended from semi-legendary, eponymous founders who had emerged to prominence in the tenth-century era of the control of northern Italy by the German Emperors of the Ottonian dynasty. The house of Montferrat derived from one Aleramo, hence called the Aleramici, or Aleramics. The house of Savoy descended from Humbert or Umberto 'of the White Hands', hence the Ubertinidi or Humbertines. Over the generations, both dynasties developed widespread matrimonial connections: Savoy especially with French families, including the Capetian royal house; Montferrat with both French royal and German imperial ties. Both lines of princes struggled continuously: to assert control over their local feudatories, to come to terms with powerful clerical princes, and eventually to deal with the challenges of independent-minded urban centers--that of Turin for Savoy, and Alessandria for Montferrat.

Dependent for their status on the favor of nominal suzerains, the Aleramics of Montferrat and the Humbertines of Savoy were at first but two among many of the lesser and distinctly regional princely families of medieval Europe, at a time when the sorting out of hierarchies and gradations of nascent states was still in progress. But, as parts of still-amorphous Italian regions, each of our two houses was caught up in the ferment brewing in the Mediterranean world by the end of the eleventh century.

As preached by Pope Urban II in 1095, the First Crusade was a prime symbol of that ferment. It marked the first military intrusion of Western Europeans into the Eastern Mediterranean and Middle-Eastern world, culminating in the conquering Jerusalem and establishing a Crusader Kingdom in 1099, with a network of connected feudal principalities. That new world of Outremer created great possibilities for the enterprising, not to say the opportunistic. Given their circumstances, however, that epoch-making movement came too early for either house to become immediately or directly involved. To be sure, Count Humbert or Umberto II (r.1080-1103) is supposed to have indicated an intention, never fulfilled, to participate in that venture ${ }^{3}$.

3 Haberstumpf (1995): 192. This possibility is overlooked by Previté Orton (1912): 266-277, in his treatment of Humbert II. Humbert's wife, Gisela, was sister to the subsequent Pope Calixtus II, who would encourage the Second Crusade, in which her son would serve. 
It was not until the Second Crusade, which lasted from 1145 to 1148 , that the two houses truly bestirred themselves. Count Amadeus III of Savoy (r. 1103-48) seems already to have made a private crusading venture to the Holy Land in 1111. But his participation in the new and major expedition was prompted by his connections with Pope Eugenius III and with King Louis VII of France, as well as by the preaching of Bernard of Clairvaux and by the persuasion of his neighbor and stepbrother, the Marquis of Montferrat ${ }^{4}$. For the latter, however, the Second Crusade was an eagerly welcomed opening of opportunity. Marquis William V 'the Old' of Montferrat (r. 1135-88) was a bold and ambitious leader who, having strengthened his hold on his feudatories at home, welcomed the call to the golden East. Attached to his kinsman the King of France, William became an important figure in the Crusader's councils, and served with honour in the Holy Land. ${ }^{5}$ In the process, he came to know another kinsman, the future German Emperor, Frederick of Swabia, as well as the Byzantine Emperor Manuel I Komnenos, and many nobles of Outremer. By the time he returned home, William the Old of Montferrat surely recognized that the Levant offered enormous possibilities for his family. At the same time, Amadeus III of Savoy died during the Crusade, and the latter's successors in the years ahead were too much involved at home to renew his interest in the East. As between the two houses, Levantine initiative was clearly left for now to the Aleramics of Montferrat.

William the Old had four sons who were to be his agents of dynastic advancement ${ }^{6}$. William himself was pre-occupied with affairs at home for decades of his long rule. But he was remembered in Outremer for his commitment to crusading, while his attachment to Frederick of Swabia, now the German Emperor Frederick I Barbarossa (r.1152-1190), suggested that he could be a conduit for German assistance to the Kingdom of Jerusalem that was the focus of continuing crusader presence in the Levant. Its ruler was now the leprous and childless Baldwin IV (r.1174-1185), who needed to provide for succession. It was thus to the Montferrat court that Baldwin made recourse.

$4 \quad$ Previté Orton (1912): 309-313; on Amadeus's earlier visit, 281. It may be noted that, after the death of Amadeus III's father, Humbert II, Humbert's widow (and Amadeus's mother), Gisela, married Marquis Ranier of Montferrat who was, by a previous marriage, the father of the subsequent Marquis William the Old.

$5 \quad$ Usseglio (1926): II, 5-51. On this expedition in general, see Berry (1969); also Runciman (1952): 247-88.

$6 \quad$ For a quick survey of William's sons and their extensions, see Usseglio (1926): I, 145ff. Likewise Jacoby (1993), reprinted as article $\mathrm{N}^{\circ}$ IV in Jacoby (1997). See also Day (1988): 53-61, as part of a survey on the dealings of Genoa with the Aleramics. 
Marquis William's eldest son, William Longsword (Lungaspada), was invited to Outremer in 1176 to become husband to Baldwin's elder sister, Sibylla, and to become thereby also the immediate heir to the throne of Jerusalem. He accepted and, upon this marriage, he was invested with one of the Kingdom's important fiefdoms, the county of Jaffa and Ascalon. He seemed positioned to serve as a strong new military champion for the Kingdom. Ironically, however, William Longsword succumbed within months to malaria (or something worse), though not before fathering an heir to the throne, the future Baldwin $\mathrm{V}^{7}$.

Already grandfather to the new Crusader King of Jerusalem, Marquis William the Old soon found an opportunity for marital extension in another direction. The Byzantine Emperor Manuel I (r. 1143-80) was the third of the rulers of the house of Komnenos who was straining to restore his now-diminished Empire. One of Manual's pet plans had been to restore lost Byzantine power in Italy: after one failed effort to that end, Manuel was attempting a second one, as a challenge to the interests of German Emperor Frederick Barbarossa. Committed this time to diplomatic rather than military means, Manuel sought allies in the peninsula. William the Old, long Frederick's loyal ally, had been abandoned by the German Emperor in 1177 and left to fight alone against the rebellious Alessandria. William remembered Manuel from his time in Constantinople and he was now ready to be wooed by Byzantine gold and honours. A prestigious marriage was arranged between William's youngest son, Renier (then sixteen), and Manuel's daughter, Maria. This marriage brought to Renier the title of Caesar, suggesting a claim on succession--Manuel's only male heir being only a boy of eight. To Renier was apparently made a further award, Byzantium's second city, Thessaloniki, as some kind of fief ${ }^{8}$. The Aleramics might now dream of extending their family interests within a Byzantine regime. As this arrangement was being finalized, William's eldest surviving son, Conrad, dealt a blow to Frederick's representative in Italy, and himself joined Renier to Constantinople to share in the spectacular ceremonies attending the marriage in March 1180. But before the year was out, Manuel was dead and the struggle for the throne that consumed Constantinople during the next two years brought

7 Usseglio (1926): II, 57-59; Haberstumpf (1995): 31-42; more recently, Hamilton (2000): 101, 109-111; see also Baldwin (1969): 593; and Runciman (1952): 411.

8 See Haberstumpf (1995): 43-76, for a detailed account, with full discussion of sources; Usseglio, (1926): II, 59-64; also, Magdalino (1993): 100-01, 244-45; Brand (1968): 18-20; Madden \& Queller (1997): 28-29; Hamilton (2000): 148; Runciman (1959): 28; Barker (2003): 10. 
death to Renier and his ambitious Byzantine princess 9 .

That blow to William the Old's dynastic dreams was followed by one more disaster. When King Baldwin IV of Jerusalem died in 1185, the aged Marquis journeyed to Outremer to assist the regency for his grandson, the new boy-king, while assuming a royal fiefdom. But, barely a year later, eightyear-old Baldwin V was dead, and Jerusalem no longer had a Montferrat king. William stayed on, to participate in the fateful Battle of Hattin (4 July 1187), which opposed the Franks to Saladin. In the Frankish defeat, William was taken prisoner and held for ransom ${ }^{10}$.

Meanwhile, Marquis William's son Conrad had remained as regent in Montferrat. It was to him in the fateful year of 1187 that the family's next opening to Byzantium was offered. The Komnenian succession had come to an abrupt end with the violent overthrow of its last dynast, Andronikos I (r. 118385 ), which brought a new house to the Byzantine throne. Its first member, Isaac II Angelos (r. 1185-95), was anxious in his turn to cultivate allies in the West, and was apparently willing to make some amends for the tragedy of Renier's murder a bare five years before. Isaac invited the Montferrats to provide another groom for a Byzantine princess. At the time, Conrad's younger brother, Boniface, was already married, but Conrad was supposedly a widower at the moment. In addition, he had already had his own contact with the Byzantine court in 1180. It was therefore logical that he should go himself to take up the offer.

That spring, Conrad sailed to Constantinople where he was married to Isaac's sister, Theodora, and was given the title of Caesar, like his younger brother before him. Conrad was instantly pressed into service to help Isaac put down a serious rebellion. But, in the aftermath, Conrad felt he was being denied his perquisites and frozen out of a proper position. By then, too, news had come of Saladin's dramatic progress in the Holy Land. That was the campaign that would culminate in the epochal Battle of Hattin (4 July 1187). That battle, which shattered the forces of the Crusader Kingdom, was also the one in Conrad's father, Marquis William, would be taken prisoner; it would be followed by Saladin's capture of Jerusalem (2 Oct.) and his beleaguering of the Crusader coastal cities. Though Conrad had not yet heard the news of the battle itself, he realized that his situation in Constantinople had soured beyond reclaiming,

$9 \quad$ Brand (1968): 34, 45; Day (1988): 54-58; Jacoby (1993): 189.

10 Usseglio (1926): II, 69-76; Hamilton (2000): 217-18; Runciman (1952): 444, 459-60; Baldwin (1969): 604. For thorough analyses of the battle, see Nicolle (1993) and Kedar (1992). 
and that his (and his family's) interests now lay in Outremer. In mid-July 1187, Conrad slipped out of Constantinople, abandoning his Byzantine bride without a qualm, and sailed in due course to Syria ${ }^{11}$.

Discovering that Acre had been captured by the Muslims, Conrad sailed on to Tyre. There he became the accepted leader, directing its successful resistance to Saladin's two sieges and thereby saving the city for the Crusaders. In the process, he defied Saladin's display of Conrad's father, the captive Marquis William, under threat of execution if Conrad did not surrender Tyre. Conrad is reported to have refused emphatically, saying that his father had lived long enough. Only Saladin's charity saved the old man ${ }^{12}$.

Eventually released in 1188, William the Old joined his son in Tyre but he died soon after, leaving Conrad automatically as Marquis of Montferrat. His ambitions fired, however, Conrad by now had grander objectives. He boldly challenged the Crusader King Guy de Lusignan--discredited after his defeat at Hattin--for the royal title to Jerusalem. Having followed the example of his youngest brother in marrying a Byzantine princess, Conrad now followed the example of his elder brother, William Longsword, in marrying the latter's sister-in-law, Isabella, heiress to the throne (and herself daughter of a Byzantine princess, a Komnenian!). Conrad's claim on the Crusader throne was caught up in the toils of the Third Crusade, which brought King Richard the Lionhearted of England to the Holy Land as one of its leaders. Richard at first support King Guy, but eventually agreed to accept Conrad instead, with Guy finally allowed in compensation to found a dynastic kingdom of his own on the island of Cyprus. It was agreed that Conrad would take the throne, but only a few weeks later, before he could receive coronation on the date set, he was assassinated (28 April 1192). He left a daughter, Maria (d. 1212), to carry Montferrat name into the ongoing title to the crown of Jerusalem and, thereafter, Aleramic blood into the Hohenstaufen imperial genetic pool ${ }^{13}$.

11 Usseglio (1926): II, 77-84; Day (1988): 58-60; Jacoby (1993): 189-90; Brand (1968): 80-82, 84; Madden \& Queller (1997): 29-30; Runciman (1952): 472.

12 Usseglio (1926): II, 84-88, 93-112; Jacoby (1993): 192-94; Lane-Poole (1964): 221-22; Newby (1983):125-26; Madden \& Queller (1997): 27-8; Baldwin (1969): 616.

13 The most thorough study on Conrad as King of Jerusalem is Jacoby (1993), the bulk of which (pp. 194-225) is an exposition of Conrad's dealings with Italian maritime powers. See also Usseglio (1926): II, 113-68; Riley-Smith (1973): 112-119; Edbury (1991): 25-8; Runciman (1954): 19-20, 30-32, 64-65; (Painter, 1969): 66-68, 70-71, 80-81; Day (1988): 60-61.

Serious attempts to explain Conrad's murder go back at least to the monograph of Ilgen (1880), 127-35, or (1890): 121-28. For more recent discussions, see Lewis 
The bold Montferrat ventures into Levantine advancement by crusading and matrimony, as launched by Marquis William the Old, had certainly had their glorious moments. But they had cost his own life and had brought unhappy ends to three of his sons, with little tangible to show for it all. Still, the house of Montferrat had certainly established an impressive reputation for enterprise, leadership, and crusading zeal.

Moreover, waiting in the wings was the third of William the Old's four sons, Boniface, who was to bring the house of Montferrat to new degrees of status and respect within the nobility of Western Christendom. Boniface officially became Marquis of Montferrat with Conrad's death in 1192, though he had effectively governed the principality at least since 1187 . There he developed a court noted for its cultural brilliance. He was kin both to the King of France and to the German representative of the Hohenstaufen dynasty, Philip of Swabia (who, as it happened, was married to a daughter of Isaac II Angelos, and possibly had Eastern designs of his own). He also had close ties to the important maritime city of Genoa. He was well positioned for a great leap into fame and fortune.

That leap was his celebrated role in the Fourth Crusade ${ }^{14}$, through which Boniface would become the most famous of the Aleramics. In view of his family's background in crusading, in addition to so many other factors, he was a logical choice in 1201 to lead the impending Crusade, sharing partnership with the remarkable Doge of Venice, Enrico Dandolo ${ }^{15}$. Boniface was a pivotal

(1967): 117-18, and Bartlett (2001): 142-44.

On Conrad's daughter, 'Marchesa' or 'Marquise' Maria, heiress to the crown of Jerusalem, see Haberstumpf (1995): 77-85. It may be recalled that Maria's daughter by her husband Jean de Brienne, Isabelle-Yolande de Brienne, was married by Emperor Frederick II as his way of claiming the title to the Kingdom of Jerusalem. Their son was the ill-fated future Emperor Conrad IV. Thus did Montferrat blood flow into the final generations of the Hohenstaufen dynasts.

14 On Boniface in the Fourth Crusade and its aftermath, see Usseglio (1926): II, 169-262, which is now dated. The most important and probing study of the whole episode is now Madden \& Queller (1997), in which the role of Boniface is extensively set forth. The 800th-anniversary year has, however, produced several important new books: Angold (2003); Phillips (2004); Meschini (2004). Still useful among general accounts is the chapter by Neal \& Wolff (1969); also Runciman (1954): 107-131. On Boniface and Genoa, see Day (1988): 61-64.

15 In addition to the thorough treatment of the great Doge in Madden \& Queller (1997), not to mention so many other publications, we now have the landmark perspective by Madden (2003). Madden argues (p. 147), too, that it was not Dandolo who engineered the diversion of the Crusade to Constantinople, as used to be assumed conventionally. Rather, he insists, the diversion was clearly the work of Boniface 
figure in the expedition's diversion, first to capture the city of Zara for Venice, and then to turn off to Constantinople in support of prince Alexios (son of the deposed Isaac II, brother-in-law of Philip of Swabia). He was then the leading Latin commander of the Crusading forces that turned on the Byzantine capital and stormed it in the spring of 1204 . His prospects at their peak, Boniface was not alone in expecting he would be chosen the new Latin Emperor of Constantinople, but his very prestige made him perhaps too formidable a candidate for the other Latin barons, while the cautious Dandolo was suspicious of his connections with Venice's great rival, Genoa. Entitled to compensatory territories, Boniface may well have set his cap for Thessaloniki by virtue of his hapless younger brother's erstwhile title to it. His peers among the crusaders seem to have recognized that connection. But his actual acquisition of the city was the product of a complicated set of dealings, first with Dandolo and then with the Crusaders' council. In the process Boniface effectively sold to Venice the island of Crete initially awarded to him and, in its place, assumed vast rights to Greek territory in Europe ${ }^{16}$.

As King of Thessaloniki and suzerain over the new feudatories of Crusader Greece, Boniface brought the Aleramics to their most dazzling heights yet. But it was a position not long to be enjoyed. Boniface himself was killed in battle in 1207. A widower at the time of the Crusade, he had astutely taken as his Eastern bride the Hungarian-born widow of Isaac II Angelos. At his death, she was left as regent in Thessaloniki for their infant son Demetrios. The Montferrat Kingdom of Thessaloniki proved a weak reed, sorely beset. The most dangerous threat came from the aggressive ambitions of the vigorous ruler of Epiros, where one of several Byzantine successor-states had come into being after 1204. The pathetic Demetrios, only fifteen, was visiting in the West to secure aid at the time his mother was driven out of their realm in 1224, when Thessaloniki was taken by Epirote forces. All the while, the home principality of Montferrat itself had been under the rule of Boniface's son by an earlier marriage, who, upon his father's death, became Marquis as William VI. William seems to have pulled back from the family's tradition of Levantine involvement. Nevertheless, on behalf of his young half-brother, Marquis William organized a crusading force meant first to save but then to

(who, of course, had both his family claims and his ties to Philip of Swabia).

16 A thorough discussion of the process in which Boniface lost the Latin Imperial title is given by Marin (2003). For the latest and most thorough clarification of the process by which Boniface yielded Crete and obtained Thessaloniki, see Madden (2003): 184-90. 
recover Thessaloniki. After numerous difficulties, the expedition fell apart once it reached Greek soil in 1225, William himself dying of dysentery. Demetrios in his turn died two years later. He left his title to the Kingdom of Thessaloniki to the Hohenstaufen Emperor Frederick II, but in 1239 the latter ceded it back to the Montferrat family. The title continued to be held by the Aleramics for years to follow, with eventual consequences ${ }^{17}$.

Nevertheless, for much of the thirteenth century, the momentum of William the Old abated. The Marquise Boniface II (r. 1225-53) did participate in the Sixth Crusade (1228-29), led by his overlord, Hohenstaufen Emperor Frederick II--with whom he was not always on the best of terms. But neither Boniface II nor his successor, William VII, 'Il Gran Marchese' (r. 1253-91), paid much heed to Levantine affairs for their own sake. It is true that our families' first openings to the Lusignan Kingdom of Cyprus began at this time. In 1229 Boniface II gave his sister, Alice, to be the first bride of the boy-King Henry I (r. 1218-53). This step represented not Montferrat initiative but rather the will of Boniface's overlord, Frederick II. Moreover, Alice's death soon after (1233) amid a baronial revolt forestalled any possible Montferrat advantages in Cyprus ${ }^{18}$.

It was, however, another matrimonial episode that drew the Aleramics into one last Byzantine involvement. The new Palaiologan dynasty, restored in Constantinople after the collapse of the Latin Empire (1261), was anxious about the dangerous claims to Byzantine territory that were still being asserted in the West. The title to the Montferrat Kingdom of Thessaloniki had become a particular focus of attention. At the same time, the Montferrat Marquis William VII had been an ally of Byzantium in Italian affairs, while his military expenses made him receptive to Byzantine financial inducements. In 1284 it was agreed that the William's daughter Yolanda (Violante), then eleven years of age, should marry the second Palaiologan sovereign, Andronikos II (1282-1328). The initiative, or at least the sponsorship of the negotiations actually came from King Alfonso X of Castile (William's brother-in-law and Yolanda's uncle), with an eye toward drawing Byzantium into a broad alliance of powers opposed to Charles of Anjou, the ambitious king of southern Italy. But the more immediate point was that the Montferrat title to Thessaloniki, useless to Yolanda's father, could thus be part of the dowry brought to Byzantium by Yolanda--who was re-

17 Usseglio (1926): II, 262-278; Nicol (1957): 64, 107, 136; see also Longnon (1950).

18 Haberstumpf (1995): 119-126; Hill (1948): II, 101, 123-24; Edbury, (1991): 60, 67; Abulafia (1988): 192. 
baptized as Eirene or Irene. The implications of that title would complicate her tumultuous career as Byzantine Empress. She bore Andronikos II seven children and, as they matured, she pressed her husband relentlessly to grant them their own individual pieces of the Byzantine dynastic heritage. Andronikos resisted and the offended Empress left her husband and his capital to create a quasiindependent court of her own in Thessaloniki, on the basis of her family's rights to $\mathrm{it}^{19}$.

In counterpoint to all that, Yolanda/Eirene heritage also carried major significance for the principality of Montferrat itself. In 1307 her brother, Marquis John I, died without heir, thereby ending the male line of the Aleramics. Accordingly, Yolanda became the heiress to the title: she was not allowed to assume it for herself but she at least had the right to transmit it to one of her own male offspring. From among her children with Andronikos she first chose to send her eldest son, John, to be the requisite heir. Such a destiny for her first-born was strongly opposed by her husband and the Byzantine Patriarch. After further negotiations, it was agreed that her second son, Theodore, should become the new Marquis of Montferrat, and to his Italian post he went, at age fifteen. He eventually married a Genoese bride and, despite continued Byzantine contacts and occasional visits to Constantinople, he became fully Italianized, accepting Latin Catholicism and following Western ways ${ }^{20}$.

What is most striking about Marquis Theodore I Paleologo (r. 1305/638 ) is that he initiated a new dynasty in Montferrat, one in which the Aleramic lineage was fused with, and subsumed by, a succession that derived from Byzantium and that bore the Palaiologan name, for all its Latin assimilation. Theodore I himself remained largely preoccupied through his reign with maintaining his position in his principality. His son and successor, John II (r. 1338-72) did, to be sure, show a fleeting interest in Byzantium. At the time of the Byzantine civil war between John V Palaiologos and the usurper John VI Kantakouzenos, the Marquis John apparently had thoughts--never realized--of organizing an expedition to reclaim Thessaloniki in the name of

$19 \quad$ For the subject in general, see the comprehensive and probing article by Origone (1995), on Yolanda/Eirene, pp. 229, 233-234, and 237. Specifically on the marriage and career of Yolanda/Eirene of Montferrat, see Failler, (1999); Nicol (1994): 48-58; Laiou (1972): 44-48, 229-32, as well as her earlier article (Laiou, 1968): 387-90; Constantinidi-Bibikou (1950); Diehl (1948): 226-45, or trans. Harold Bell \& Teresa de Kerpely in the Diehl collection Byzantine Empresses (1963): 27686; Runciman (1959): 30-34; Barker (2003): 11-13; Barker (1971): 105-08.

20 Laiou (1968): 390-402. More broadly, Haberstumpf (1995): 97-117. See also Cognasso (1927). 
his grandmother, Yolanda/Eirene. And, on that basis, in his will and testament (1372) he even claimed for his family line not only Thessaloniki but also the title to the Byzantine Imperial throne itself ${ }^{21}$.

Though such claims would have later reverberations, they were not pursued as serious policy by Marquis John II or his successors. For all their Palaiologan name, the rulers of Montferrat paid little attention at all to Levantine interests through the fourteenth century.

It was exactly at this time, however, that the Humbertines of Savoy spectacularly asserted themselves in such directions. They had laboured for generations to consolidate their less developed and more fragmented territories. They struggled particularly to dominate Turin--which at some points even fell into Montferrat hands--and they shifted in their dealings with their Hohenstaufen overlords. Through all that, the lords of Savoy had been too distracted for the Levantine adventurism that had become a Montferrat preserve ${ }^{22}$. Moreover, Count Thomas I (r. 1189-1233) initiated the pernicious practice of allowing progressive subdivisions of the family lands among younger lines. Thus, the first Humbertine involvement with the Greek world was undertaken not by a member of the senior family line but by one of the Piedmont branch, Philip. He was manipulated by Pope Boniface VIII into a marriage with Isabelle de Villehardouin, the titular heiress to the crusader Principality of Achaia in the northern Peloponnesos. After their wedding in 1301, Philip of Achaia and his bride undertook some largely futile campaigning on behalf of the Latin barons in Greece, but dissatisfactions with him and intrigues against him resulted in the loss of their recognition. He still continued to insist on his right to the title of Prince of Achaia, even after the demise of Isabelle (1311). Philip died in 1324 and his son by a second marriage, and chief heir, James (Jacques) of Savoy, formally advanced his claim to the principality before his own death in 1367 . This was just so much legal maneuvering, though it was replicated by the later efforts of Jacques's two sons, Amadeus (d. 1402) and Louis (d. 1418) to assert hereditary claims to the Principality of Achaia. That gesture merely provided an excuse for the House of Savoy to persist in retaining the title, down through

$21 \quad$ Laiou (1968): 402-03; Haberstumpf (1995) 105-08; also Origone (1995): 237 and n. 22.

22 Usseglio (1926): II, 296-300, is at great pains to deny that Count Thomas I of Savoy participated in the Fourth Crusade with Boniface of Montferrat. On the concentration by the Humbertines rather on expanding their European status, see Cox (1974). 
the nineteenth century ${ }^{23}$.

The competition among rival branches of the Humbertines seemed to threaten Savoy with definitive fragmentation. That fate was forestalled, however, by the strong personality of Count Amadeus V, 'the Great' (r. 12851323), under whom the principality underwent reconstruction. Two years after his death a striking recognition of his achievement came from Byzantium. In the summer of 1325, an embassy from Constantinople appeared at the court of Amadeus's son and successor, Edward (r. 1323-29), to ask that the latter's halfsister, Joanna (Giovanna) become the bride of the Emperor Andronikos III (r. 1328-41). Why a lady from a Latin court with virtually no prior contact with Byzantium should have been solicited is not clear. There are indications that some influence to this end was exerted by Marquis Theodore I of Montferrat. His family already had its own connections by marriage with the Humbertines, and he was himself in Constantinople, on one of his visits there, at the time of the decision. It is said that Joanna had also been sought in marriage by King Charles IV of France, but a Byzantine connection still had irresistible attractions in the West. The proposal was accepted, the lady arrived in Constantinople for her marriage the following year, and she became known to history thereafter as Anna of Savoy.

She was to be a prime figure in the tumultuous events of mid-fourteenthcentury Byzantium. Upon the premature death of her husband in 1341, she became regent for their son, John V Palaiologos (r. 1341/55-91). Swayed by the self-serving advice of the ambitious courtier Alexios Apokavkos, Anna became the implacable enemy of her late husband's chief counselor, John Kantakouzenos. The latter felt driven to claim the throne for himself as John VI (r. 1347-55), pushing Anna and her son aside. After renewed struggles, John $\mathrm{V}$ was able to recover his throne. Disaffected from him, Anna withdrew into the comfortable rule of the city of Thessaloniki (1352-65), virtually in her own right. Though she did have some distant family connections with the house of Montferrat, it was simply by virtue of her status as dowager-empress that she could assume this power. That she could do this is a significant indicator of the degree of decentralization to which the withered Byzantine Empire had descended. It is noteworthy, however, that Anna had blended so totally into the Byzantine world: she seems never to have considered returning to her homeland, as old accounts used to suggest she did. Rather, she ended her days

23 Topping (1975): 134; Haberstumpf (1995): 205-24; Miller (1908): 194-206; Lock (1995): 102-103, 108-09. On Isabelle de Villehardouin, see Kiesewetter (1999): 399-43. 
as an Orthodox nun, under the name of Anastasia, while still mistress of the city she had claimed for herself ${ }^{24}$.

If Anna of Savoy's stormy career brought her family into dramatic involvement with Byzantium, it was her nephew who made the most sensational Humbertine impact on Byzantium. He was, at the same, the first (and only) prince of the house Savoy to undertake a direct crusading venture. Nephew of the short-lived Count Edward and son of his brother and successor Aymon (r. 1329-43), Amadeus VI, 'the Green Count' of Savoy (r. 1343-83) was also of Aleramic blood, through his mother, Countess Yolanda (Violante) of Montferrat. In that sense he symbolized a fusion of the two dynasties' interest in the Eastern Mediterranean. Emerging from his minority to further the territorial consolidation of the still-nascent Savoyard state (including confrontations with the Achaian branch of the family), Amadeus moved then to enhance his prestige through crusading. He first committed himself in 1364 to the crusade project being organized by King Peter (Pierre) I de Lusignan, even founding a military order of his own. But then, on the prompting of Pope Urban V, Amadeus became interested in collaborating with King Louis 'the Great' of Hungary who had grand schemes for fighting the Turks in the Balkans. At the same time, his sympathies were kindled for his Byzantine cousin, Emperor John V Palaiologos. We may recall the genealogical tangles behind all this. The Green Count and Emperor John were first cousins, as grandsons of Count Amadeus V. But Amadeus VI was also a great-grandson of Emperor Andronikos II by way of his Montferrat mother, who was a granddaughter of Yolanda/Eirene of Montferrat. Suggestion has even been made that Amadeus VI had specific ambitions of claiming the throne of Constantinople for himself, which seems far-fetched.

As Hungarian plans shifted, Amadeus set out with his crusading force in 1366. After some distractions, he seized from the Turks the crucial stronghold of Gallipoli on the Dardanelles. John V had meanwhile journeyed to Buda in a vain effort to win aid against the Turks from King Louis. When the ill-disposed

$24 \quad$ On this remarkable woman, see the full-scale biographical and historical study by Origone (1999), which quite supersedes the once-classic study is Muratore (1909), now outdated on many counts. See also Origone (1995): 230, 235, 238-40; as well as the chapter on Anna in Nicol (1994): 82-95, which is an advance over the older sketch by Diehl (1948): II, 245-70; or in Diehl (1963): 287-308. Further, see Nicol \& Bendall (1977); Haberstumpf (1995): 195-196, 225-232; and Barker (2003): 22.

Anna's marriage and her deep involvement in Byzantine political life may be traced in a number of broader studies: Laiou (1972); Bosch (1965); Nicol (1996), and Nicol (1993). 
Bulgarians blocked John's return home, Amadeus struck at Bulgarian costal points to resolve the problem. When they were united at last in Constantinople the following year, Amadeus entered into discussions with the Emperor and his clergy with the goal of Greek Church submission to the Papacy. Before his own return home, the Count persuaded John to journey in person to Rome. The feckless Emperor did just that two years later, making his personal conversion to Latin Catholicism, but with no actual effect on the schism. Little substantive resulted from either Amadeus's crusade or John's conversion. Nevertheless, the whole episode rocketed the Green Count to the highest esteem as a chivalrous champion of the Latin faith ${ }^{25}$.

From Eastern affairs Amadeus turned thereafter to Western ones. In the years following his crusade he was caught up in tangled local affairs, alliances, and military operations, not to mention the Great (Western) Church Schism of 1378--which brought a cousin of his to the rival Papal throne of Avignon as Clement VI. But Amadeus's sense of moral obligation prompted him to offer mediation between the republics of Genoa and Venice, then locked in the socalled Chioggia War that had begun over rival claims to the Byzantine island of Tenedos. That mediation resulted in the Treaty of Turin (Aug. 1381), resolving the conflict--though, ironically, without consideration of the interests of Amadeus's Byzantine cousin John V Palaiologos. ${ }^{26}$ Such a diplomatic triumph established Amadeus's reputation as a statesman of international stature, beyond being a great soldier as well. It is said that, amid his local distractions, Amadeus perhaps contemplated a new crusade, one directly aimed at the Holy Land. But that is speculation. Caught up in a new Italian campaign, Amadeus died in $1383^{27}$.

The Green Count's immediate descendants found themselves totally involved in their local affairs. His son and successor, Amadeus VII, 'the Red Count' (r. 1383-91) did lend diplomatic support to a brief effort by a cousin, Amadeus of Achaia, to claim the elusive rule of the Latin Morea in 1386-91), but he did little beyond that ${ }^{28}$. The next Humbertine, grandson Amadeus VIII

25 The old study by Cognasso (1926/30) -in which see pp. 154-81 -is now superseded by Cox (1967), in which see 204-239. More recent is Bollati di SaintPierre (1900). See also: Geanakoplos (1969): 74-78; Atiya (1938): 379-97; Housley (1992) : 67-69; Delaville le Roulx (1886): 140-158; Bouquet (1958); Halecki (1930):

111-37; Meyendorff (1960); Barker (1968) : 7-9; Nicol (1993) : 265-69.

26 Cox (1967): 321-323; Barker (1968): 40-41; Nicol (1993): 283.

27 Cox (1967): 328-30.

28 Topping (1975): 152-57. 
'the Peaceful' (r. 1391-1434), completed consolidation of family territories. He won the grander title of Duke in 1416 and then, in 1424, the title of Prince of Piedmont, definitively replacing Chambéry with Turin as his capital. Ironically withdrawing into contemplative life, he allowed himself to be drawn into the so-called Conciliar Movement, aimed at opposing Papal autocracy in the Church with the mechanism of regular councils. This movement culminated in the ill-starred Church Council of Basel (1431-43), and Amadeus accepted its election as the Antipope Felix V (1439-49). When that role dissolved after the Council's collapse, Amadeus/Felix accepted reconciliation with the pope and ended his days as a pampered cardinal in Rome ${ }^{29}$.

After the death of Amadeus VI, however, no subsequent members of the Savoy dynasty showed any disposition to personal involvement in Levantine projects--though, to be sure, matrimonial connections were recurrently fostered to keep Eastern interests alive. The same can be said for the Paleologhi of Montferrat. They did, however, have one final and ephemeral connection with Byzantium. In the aftermath of the great reformist Council of Constance (1414-18), Emperor Manuel II Palaiologos (r. 1391-1425) was sparring diplomatically with the new Pope Martin V over possible Western aid to Byzantium in exchange for possible Church Union and Byzantine conversion to Latin Catholicism. Since the Emperor's two eldest sons--his heir, the future John VIII, and the Despot Theodore I of the Morea--were in need of brides, Manuel had his agents negotiate marriages for them with members of prominent Italian princely families. Through Papal initiative, therefore, a member of the Montferrat house was chosen to be the future basilissa or Empress as John's bride. As a daughter of the (recently deceased) Marquis Theodore II Paleologo and great-granddaughter of Marquis Theodore I, Sophia of Montferrat was actually a distant cousin of the Byzantine prince. Balancing Sophia's selection, Cleopa Malatesta of Rimini was destined for Despot Theodore.

The two brides sailed East in 1420, to spouses who hated them, in marriages that were misery for everybody. Sophia's wedding to John in January 1421 was linked with the latter's coronation as co-Emperor. The poor girl seems to have been quite unattractive: one cruel quip of the day had it that her appearance was like 'Lent in front, Easter behind'! John found her repulsive and, it is said, even refused to consummate the marriage. There is a false tale that the despairing Sophia attempted to flee and, on Manuel's order, was not prevented. We know, instead, that John bided his time with her out of respect 
for his father but that, when Manuel died (1425), John renounced the marriage and the wretched woman was sent packing. Fleeing to her homeland, Sophia found refuge for her remaining days in a convent ${ }^{30}$.

For the houses of both Montferrat and Savoy, however, matrimonial machinations aimed as Levantine advantage were being transferred to the only important survivor among crusader-created regimes, the Lusignan Kingdom of Cyprus. We have already noted the short-lived and profitless marriage (122933) of Alice, sister of Marquis Boniface II of Montferrat, to King Henry I of Cyprus. Over two centuries later, there seemed more prospects in the marriage of Amedea (Medea) Paleologo of Montferrat to King John (Jean) II de Lusignan (r. 1438-52), by proxy in 1437 and in person in 1440. Amedea was, after all, not only a niece of the unfortunate Sophia, bride of Emperor John VIII; she was also a great-great-granddaughter of Marquis Theodore I Paleologo and hence a descendent of Andronikos II Palaiologos by Yolanda/Eirene. That made her a Palaiologina by descent, and thus of value to her husband in cultivating the loyalty of his Greek Cypriote subjects. But after only two months of the marriage Amedea died under mysterious circumstances, and John II turned instead to a more immediately Byzantine princess: Helena, daughter of Despot Theodore II of the Morea ${ }^{31}$.

Now was the turn of the house of Savoy on Cyprus. Not long before, in 1433, Louis (Ludovico) of Geneva, about to become Duke of Savoy (r. 1434-65), married Anna de Lusignan, a daughter of King Janus de Lusignan (r. 1398-1432) and sister of King John II of Cyprus. A quarter-century later, a succession struggle over the Cypriote crown was looming between James, King's John's natural son (by a youthful liaison), and his legitimate daughter by Helena, Charlotte (Carlotta). It was arranged by the young Charlotte's faction that she marry her first cousin, the second son of Duke Louis and Duchess Anna of Savoy, Count Louis of Geneva. This marriage was celebrated in October 1459 , but only after the death of John II the previous year and after Charlotte's coronation--with the Lusignan triple crown, adjoining to Cyprus the titles to the thrones of Jerusalem and Armenia. Louis proved to be a weak supporter to Charlotte and after two years they fled Cyprus for Savoy in the face of

$30 \quad$ The vivid (if partly fanciful) Byzantine account of this unhappy marriage by Doukas, ed. Grecu (1958): XX, 6, pp. 137-39, includes the cruel quip (p. 137, lines 18-19); trans. Harry J. Magoulias, Doukas (1975): 113-14. In general, Origone (1995): 230-31, 236, 240-41; and Runciman (1981). See also Haberstumpf (1995): 135-38; Barker (1968): 348-50; Diehl (1963): II, 272-75; Nicol (1993): 330-31; Gill (1959): 24.

31 Hill (1948): III, 526-27; Luke (1975): 376; Haberstumpf (1995): 126-134. 
the irresistible takeover by her half-brother, James. After two more years of strife, James II reigned (1464-73) as the last true Lusignan sovereign of the island. Charlotte and Louis maintained her claims to Cyprus, but Louis died in futility in 1482, and she followed him five years later. Long before that she had prepared a dynastic gift. In 1462, while seeking Savoy's help, Charlotte had signed an agreement by which, should she and Louis have no children, her claims would revert to her mother-in-law, Duchess Anna of Savoy (daughter of King Janus) and to her descendants. Aside from an abortive venture to Egypt on her own behalf in 1478, Charlotte took up residence in Rome as an exile. In 1485 she confirmed the agreement of 1462 by making a formal cession of her Cypriote claims to Duchess Anna's grandson, Duke Charles (Carlo) I of Savoy (r. 1482-89) $)^{32}$.

Meanwhile, the marriage of James II to the Venetian Catherine Cornaro, then his premature death, and then the puppet reign of Queen Catherine (147389), paved the way for the Republic of Venice to assume control of Cyprus, made official in $1489 .{ }^{33}$ That sequence of events made the Savoy claims to Cyprus unrealistic, while Venice's loss of the island to the Turks in 1571 made them a mere formality. ${ }^{34}$ Nevertheless, along with the style of Prince of Achaia, the Lusignan triple crown of Cyprus, Jerusalem, and Armenia was now added to the bundle of claims that was borne by the dynasts of Savoy down to the abdication of King Victor Emanuel III of Italy in 1946 and the deposition of his son, Humbert II, months later.

Looking back over this panorama of four centuries, one is struck not by the presence of patterns but by their absence. Each of our two dynasties-more especially the Montferrats--relished moments of international prestige and influence thanks to either or both crusading and matrimonial involvements in the East. Yet, those involvements seem not to have represented continuing programs in such direction. Rather, when they were not fortuitous results of outside influences, they reflected the ambitions of specific and comparatively unusual members of the two families: such assertive personalities as William the Old of Montferrat and his sons--notably Conrad and Boniface--or Amadeus VI of Savoy. Only the slightest echo of their glory might be found in career of a member the spin-off Soissons branch of the Savoy family, Prince Eugène of Savoy (1663-1736), who made his career in the service of the Hapsburg

32 Hill (1948): III, 532-533, 543-544, 548-550, 554ff, 594-619; Luke (1975): $379-86$.

33 Hill, (1948): III, 657-764; Luke (1975): 386-93.

34 Luke (1975): 878-1040; Setton (1984): 974-1044. 
Emperors and became the great Austrian champion who turned the Christian tide against the Turks in the Balkans ${ }^{35}$. In general, however, most ruling princes of the two mainstream houses concentrated instead on building their realms in Italy and on consolidating matrimonial ties with other European dynasties. Yet, if ephemeral, their colorful achievements on the Levantine stage in some ways did complement and enhance their cumulative accomplishments at home.

Meanwhile, with the age of true crusading ended and with no prospects remaining for emulating their heroic forebears, the two dynasties moved to a point of junction. They had, after all, long had close connections, exchanging episodes of protection or dependency, and with recurrent ties forged through matrimony.

Perusal of the appended dynastic tables may help clarify these ties. We may first recall that Gisela, the widow of Count Humbert II of Savoy (r.10801103) and mother of Count Amadeus III (r. 1103-1148), had taken as her second husband the Marquis Rainier of Montferrat (r. 1100-1135), father of William V 'the Old' (r. 1135-1190). A daughter of Count Amadeus IV of Savoy (r. 123353), Margaret (Margherita), was married to Marquis Boniface II of Montferrat (r. 1229-53). More dramatically, there was an exchange of family marriages decades later, if at wide intervals: another Margaret/Margherita of Savoy, daughter of Count Amadeus V (r. 1285-1323), became in 1296 a child bride to Marquis John I (r. 1291-1307); while, conversely, Amadeus V's son and successor-after-one, Aymon (1329-43), in 1330 married Yolanda of Montferrat, daughter of Marquis Theodore I Paleologo (1305-1338) and namesake of his mother the Byzantine basilissa. A still later case in point was the marriage in 1411 of Joanna (Giovanna) of Savoy, daughter of Amadeus VII 'the Red Count' (r. 1383-91), to Marquis Giangiacomo of Montferrat (r. 1418-45).

The most significant of these unions, of course, was that of Aymon of Savoy with Yolanda of Montferrat, who became parents of Amadeus VI 'the Green Count'. Their 1330 marriage contract apparently envisioned that, in the event of the extinction of the Paleologo line, the Marquisate of Montferrat would devolve upon the house of Savoy. That commitment might have seemed a distant memory when, with the death of Marquis Giangiorgio Paleologo in 1533, the Montferrat dynasty became extinct. Claim was made to it by Duke Charles (Carlo) II (r. 1504-53) but, under the adjudication of the Hapsburg Holy Roman Emperor Charles V, the Montferrat territories were awarded to a rival contender, the Gonzaga Duke of Mantua. Successive stages of Gonzaga

35 The major study is Braubach (1963-65). See also Henderson (1964) and McKay (1977). 
control lasted through the seventeenth century. Only in 1708 did the Montferrat heritage fall to the house of Savoy, an acquisition then confirmed in 1713 by the Treaty of Utrecht, which ended the Europe-wide War of Spanish Succession. The Savoy Duke took the title of king from brief control of Sicily, which in 1720 was exchanged for Sardinia. By then, the Humbertines were well on their way, as Kings of Sardinia-Piedmont, to become the dynasty under which all Italy would be united ${ }^{36}$.

I recall reading somewhere a story, probably apocryphal, about the Greek War of Independence. The story had it that the Greek provisional government during the 1820 s sent out a delegation to seek in Europe any legitimate descendent of the Palaiologan dynasty who might become candidate for neoByzantine sovereign of the new nation. Supposedly nothing came of this quest, even though several modern families have claimed to preserve the venerable dynastic name. Had there been such a delegation, it could have found a much better choice than the subsequent one that was made of Otto of Bavaria to be the first King of modern Greece. It could simply have looked at the house of Savoy, then ruling the Kingdom of Sardinia-Piedmont. That house stands, after all, as the longest-surviving continuous-reigning dynasty in all of European history. And, in the veins of its still-living descendants runs the blood not only of Boniface of Montferrat and Amadeus VI of Savoy but also of the Byzantine Palaiologoi. They are, in effect, the ultimate fruit of dynastic enterprise and matrimony in the age of the Crusades.

\section{BIBLIOGRAFÍA}

ABULAFIA, D. (1988). Frederick II, A Medieval Emperor . London: Oxford University Press.

ANGOLD, M. (2003). The Fourth Crusade: Event and Context. Harlow: Pearson Longman.

ATIYA, A. S. (1938). The Crusade in the Later Middle Ages. London: Methuen.

BALDWIN, M. M. (1969). The Decline and Fall of Jerusalem. In K. Setton, \& M. Baldwin (Eds.), A History of the Crusades (Vol. I: The First Hundred Years, pp. 590-621). Madison WI: Wisconsin University Press.

$36 \quad$ For this aftermath, appropriate specialized studies are scanty. More broadly, however, some important books are the ones of Carutti (1875-1880); Cochrane (1988); Osborne (2002); Symcox (1983); Di Scala (1995); Hearder (1983); finally, three books by Mack Smith $(1959,1968,1989)$. On the Savoy house's use of architecture and religious symbolism, see Scott (2003); and on their capital, see Pollak (1991). 
BARKER, J. W. (1968). Manuel II Palaeologus (1391-1425): A Study in Late Byzantine Statesmanship. New Brunswick NJ: Rutgers University Press.

BARKER, J. W. (1971). The Problem of Appanages in Byzantium. Byzantina, 3 , 10522.

BARKER, J. W. (2003 ). Late Byzantine Thessalonike: A Second City's Challenges and Responses. Dumbarton Oaks Papers, 57, 5-33.

BARTLETT, W. B. (2001). The Assassins: The Story of Medieval Islam's Secret Sect . Stroud UK: Sutton.

BERRY, V. G. (1969). The Second Crusade Marshall W. Baldwin. In K. Setton, \& M. Baldwin (Eds.), A History of the Crusades (2nd ed., Vol. I: The First Hundred Years, pp. 463-512). Madison WI: University of Wisconsin Press.

BOLLATI DI SAINT-PIERRE, F. E. (1900). Illustrazioni della spedizione in Oriente di Amadeo VI. Turin: Fratelli Bocca.

BOSCH, U. V. (1965). Kaiser Andronikos III. Palaiologos: Versuch einer Darstellung der byzantinischen Geschichte in den Jahren 1321-1341. Amsterdam: A. Hakkert.

BOUQUET, J. J. (1958). Remarques sur l'idée de croisade dans l'expedition d'Amadée VI de Savoie à Constantinople. Bulletin annuel de la Fondation Suisse, 7 , 17-33.

BRAND, C. M. (1968). Byzantium Confronts the West, 1180-1204. Cambridge MA: Harvard University Press.

BRAUBACH, M. (1963-65). Prinz Eugen von Savoyen. Munich: R. Oldenbourg.

CARUTTI, D. (1875-1880). Storia della diplomazia della corte di Savoia dal 1494 al 1773. Roma: Frattelli Bocca.

COCHRANE, E. (1988). Italy, 1530-1630. (J. Kirshner, Ed.) London \& New York: Addison-Wesley Longman Limited.

COGNASSO, F. (1926/30). Il conte verde (1334-1385). Turin: G. B. Paravia.

COGNASSO, F. (1927). Una crisobola di Michele IX Paleologo per Teodoro I di Monferrato. Studi bizantini, 2 , 39-47.

CONSTANTINIDI-BIBIKOU, H. (1950). Yolande de Montferrat, impératrice de Byzance. L'Hellénisme contemporain, II, 4, 425-42.

COX, E. L. (1967). The Green Count of Savoy: Amadeus VI and Transalpine Savoy in the fourteenth Century. Princeton: Princeton University Press.

COX, E. L. (1974). The Eagles of Savoy: The House of Savoy in Thirteenth-Century Europe. Princeton: Princeton University Press.

DAY, G. W. (1988). Genoa's Response to Byzantium, 1155-1204: Commercial Expansion and Factionalism in a Medieval City. Urbana IL: University of Illinois Press.

DELAVILlE LE ROULX, J. (1886). La France en Orient au XIVe siècle. Paris: Libraire des Écoles françaises d'Ath'enes et de Rome du Collège de France et de l'École Normale Supérieure. 
DI SCALA, S. M. (1995). Italy: From Revolution to Republic, 1700 to the Present. Boulder \& Oxford: Westview Press.

DIEHL, C. (1948). Figures byzantines (Vol. II). Paris: Colin.

DIEHL, C. (1963). Byzantine Empresses. (H. Bell, \& T. Kerpely, Trads.) New York: Knopf.

DOUKAS. (1958). Historia Turco-Byzantina. (V. Grecu, Ed.) Bucharest: Editura Academiei Republicii populare romîne.

DOUKAS. (1975). Decline and Fall or Byzantium to the Ottoman Turks by Doukas. (H. Magoulias, Ed.) Detroit: Wayne State University Press.

EDBURY, P. W. (1991). The Kingdom of Cyprus and the Crusades, 1191-1374. Cambridge: Cambridge University Press.

FAILLER, A. (1999). Le second mariage d'Andronic II Palaiologos. Revue des Études Byzantines, 57 , 225-35.

GEANAKOPLOS, D. J. (1969). Byzantium and the Crusades, 1354-1453. En H. Hazard (Ed.), A History of the Crusades (Vol. III: The fourteenth and fifteenth centuries, pp. 69-103). Madison WI: University of Wisconsin Press.

GILL, J. (1959). The Council of Florence. Cambridge: Cambridge University Press. HABERSTUMPF, W. (1995). Dinastie europee nel Mediterraneo orientale: I Monferrato e i Savoia nei secoli XII-XV. Turin: Scriptorium.

HALECKI, O. (1930). Un Empereur de Byzance à Rome: Vingt ans de travail pour l'Union des églises et pour la defence de l'empire d'Orient, 1355-1373. Warsaw: Travaux historiques de la Société des sciences et des lettres de Varsovie.

HAMILTON, B. (2000). The Leper King and his Heirs: Baldwin IV and the Crusader Kingdom of Jerusalem. Cambridge: Cambridge University Press.

HEARDER, H. (1983). Italy in the Age of the Risorgimento, 1790-1870 . London \& New York: Longman.

HENDERSON, N. (1964). Prince Eugene of Savoy. London: Weidenfeld and Nicolson. HILL, G. (1948). A History of Cyprus (Vol. II: The Frankish Period, 1192-1432). Cambridge: Cambridge University Press.

HILL, G. (1948). A History of Cyprus (Vol. III: The Frankish Period, 1432-1571). Cambridge: Cambridge University Press.

HOUSLEY, N. (1992). The Later Crusades: From Lyons to Alcazar, 1274-1580. Oxford: Oxford University Press.

ILGEN, T. (1880). Margraf Conrad von Montferrat. Marburg: N. G. Elwert.

ILGEN, T. (1890). Corrado Marchese di Monferrato. (G. Ceratto, Trad.) Casale: Carlo Cassone.

JACOBY, D. (1993). Conrad, Marquis of Montferrat and the Kingdom of Jerusalem (1187-1192). En L. Balletto (Ed.), Atti del'Congresso Internazionale 'Dai feudi monferrini e dal Piemonte ai nuovi mondi oltre gli Oceani', Alessandria, 2-6 Aprile 1990 (pp. 187-238). Alessandria: Società di storia, arte, e archeologia, Accademia degli immobili. Reprinted in Jacoby, D. (1997). 
Trade, Commodities and Shipping in the Medieval Mediterranean. Aldershot: Variorum.

KEDAR, B. Z. (1992). The Battle of Hatin Revisited. En B. Kedar (Ed.), The Horns of Hattin (pp. 190-207). Jerusalem \& London: Variorum.

KIESEWETTER, A. (1999). Die Anfänge der Regierung König Karls II. von Anjou (1278-1295): Das Königreich Neapel, die Grafschaft Provence und der Mittelmeerraum zu Ausgang des 13. Jahrhunderts. Husum: Matthiesen Verlag. LAIOU, A. (1968). A Byzantine Prince Latinized: Theodore Palaeologus, Marquis of Montferrat. Byzantion, 38 , 386-410.

LAIOU, A. (1972). Constantinople and the Latins: The Foreign Policy of Andronicus II, 1282-1328. Cambridge MA: Harvard University Press.

LANE-POOLE, S. (1964). Saladin and the Fall of the Kingdom of Jerusalem . Beirut: Khayats.

LEWIS, B. (1967). The Assassins: A Radical Sect in Islam. London: Widenfeld and Nicholson.

LOCK, P. (1995). The Franks in the Aegean, 1204-1500 . London \& New York: Longman.

LONGNON, J. (1950). La reprise de Salonique par les Grecs en 1224. Actes du VIe Congrès international d'études byzantines. I, pp. 141-46. Paris: École des hautes études.

LUKE, H. (1975). The Kingdom of Cyprus, 1369-1489. En A History of the Crusades (Vol. III: The fourteenth and fifteenth centuries, pp. 361-395). Madison WI: University of Wisconsin Press.

MACK SMITH, D. (1959). Italy, A Modern History. Ann Arbor: University of Michigan Press.

MACK SMITH, D. (Ed.). (1968). The Making of Italy, 1796-1860. New York: Walker and Company.

MACK SMITH, D. (1989). Italy and its Monarchy. New Haven: Yale University Press.

MADDEN, T. F. (2003). Enrico Dandolo and the Rise of Venice. Baltimore: Johns Hopkins University Press.

MADDEN, T. F., \& Queller, D. (1997). The Fourth Crusade: The Conquest of Constantinople (2nd ed.). Philadelphia: University of Pennsylvania Press.

MAGDALINO, P. (1993). The Empire of Manuel I Komnenos, 1143-1180. Cambridge: Cambridge University Press.

MARIN, S. (2003). The Venetian "Empire" in the East. The Imperial Elections in Constantinople in 1204 in the Venetian Chronicles' Representation. Annuario del'Istituto Romeno di Cultura e Ricerca Umanistica di Venezia 5 , 185-245.

MCKAY, D. (1977). Prince Eugene of Savoy . London: Thames and Hudson.

MESCHINI, M. (2004). 1204: L'incompiuta. La quarta crociata e le conquiste di Costantinopoli. Milan: Àncora.

MEYENDORFF, J. (1960). Projets de Concile oecuménique et le légat Paul. Dumbarton Oaks Papers, 14 , 149-77. 
MILLER, W. (1908). The Latins in the Levant: A History of Frankish Greece (12041566). London: Murray.

MURATORE, D. (1909). Una principessa sabauda sul trono di Bisanzio. Mémoires de l'Académie des Sciences, Belles-lettres et Arts de Savoie, IV, 11 , 221-475.

NEAL, E. H., \& WOLFF, R. (1969). The Fourth Crusade. En K. Setton, \& M. Baldwin (Edits.), A History of the Crusades (Vol. I: The First Hundred Years, pp. 15386). Madison WI: University of Wisconsin Press.

NEWBY, P. H. (1983). Saladin in his Time . London: Barnes \& Noble Books.

NICOL, D. M. (1957). The Despotate of Epiros. Oxford: Basil Blackwell.

NICOL, D. M. (1993). The Last Centuries of Byzantium, 1261-1453 (2nd ed.). Cambridge: Cambridge University Press.

NICOL, D. M. (1994). The Byzantine Lady: Ten Portraits, 1250-1500 . Cambridge: Cambridge University Press.

NICOL, D. M. (1996). The Reluctant Emperor: A Biography of John Cantacuzene, Byzantine Emperor and Monk, c.1295-1383 . Cambridge: Cambridge University Press.

NICOL, D., \& BENDALL, S. (1977). Anna of Savoy and Thessalonica: The Numismatic Evidence. Revue Numismatique, 19, 90-102.

NICOLLE, D. (1993). Hattin 1187: Saladin's Greatest Victory . London: Osprey Publishing.

ORIGONE, S. (1995). Marriage Connections between Byzantium and the West in the Age of the Palaiologoi . Mediterranean Historical Review, 10, 226-41.

ORIGONE, S. (1999). Giovanna di Savoia, alias Anna Paleologina, latina a Bisanzio (c.1306-c.1365). Milan: Jaca Book.

OSBORNE, T. (2002). Dynasty and Diplomacy in the Court of Savoy: Political Culture and the Thirty Years' War . Cambridge: Cambridge University Press.

PAINTER, S. (1969). The Third Crusade: Richard the Lionhearted and Philip Augustus. In R. Wolff, \& H. Hazard (Eds.), A History of the Crusades (2nd ed., Vol. II: The Later Crusades, 1189-1311, pp. 45-86). Madison WI: University of Wisconsin Press.

PHILLIPS, J. P. (2004). The Fourth Crusade and the Sack of Constantinople. New York: Jonathan Cape.

POLLAK, M. D. (1991). Turin 1564-1680. Urban Design. Military Culture and the Creation of the Absolute State. Chicago: University of Chicago Press.

PREVITÉ ORTON, C. W. (1912). The Early History of the House of Savoy (10001233) . Cambridge: Cambridge University Press.

RILEY-SMITH, J. (1973). The Feudal Nobility and the Kingdom of Jerusalem, 11741277 . London: Macmillan.

RUNCIMAN, S. (1952). A History of the Crusades (Vol. II: The Kingdom of Jerusalem and the Frankish East, 1100-1187). Cambridge: Cambridge University Press.

RUNCIMAN, S. (1954). History of the Crusades (Vol. III: The Kingdom of Acre and the Later Crusades ). Cambridge: Cambridge University Press. 
RUNCIMAN, S. (1959). Thessalonica and the Montferrat Inheritance. Grigórios o Palamâs, 42, 27-35.

RUNCIMAN, S. (1981). The Marriages of the Sons of the Emperor Manuel II. Rivista di studi bizantini e slavi, 1, 273-82.

SCOTT, J. B. (2003). Architecture for the Shroud: Relic and Ritual in Turin. Chicago: University of Chicago Press.

SETTON, K. M. (1984). The Papacy and the Levant (1204-1571)(Vol. IV). Philadelphia: American Philosophical Society.

SYMCOX, G. (1983). Victor Amadeus II: Absolutism in the Savoyard State, 16751730. London: University of California Press.

TOPPING, P. (1975). The Morea, 1311-1364. En H. Hazard (Ed.), A History of the Crusades (Vol. III: The Fourteenth and Fifteenth Centuries, pp. 104-140). Madison WI: University of Wisconsin Press.

TOPPING, P. (1975). The Morea, 1364-1460. En H. Hazard (Ed.), A History of the Crusades (Vol. III: The fourteenth and fifteenth centuries, pp. 141-66). Madison WI: University of Wisconsin Press.

USSEGLIO, L. (1926). I Marchesi di Monferrato in Italia ed in Oriente durante i secoli XII e XIII. Turin, 1926 : Tip. di Miglietta, Milano e C. 


\section{APPENDIX \\ Crusading and Hatrinony in the Eastem Hediterranean: \\ The Dymastic Policies of Montferrat ard Sayoy}

\section{Dymastic lines and involvenents}

( 811 dates are regnal, some early ones uncertain; manes in Italian form)

\section{MONTFERRhI:}

\section{Aleranici}

Guglielmo I (990-1020)

Enrico $(1020-45)$

Guglielmo II (1045-83)

Guglielmo II! (1083-96)

Guglielmo IV (1096-1100

Ranieri $(1100-35)=$ = $<------$ Gisela

Guglielmo $Y$ il Yecchio $(1135-90)$
Alerano (ca.950-91)

SRBOY:

Humbertinidi
Unberto I dalle Bianche
Mani (d.1047/48)
Madeo I (1048-51)
Pietro I (1051-78)
Imadeo II (1078-80)
Umberto II (1080-1103)
C (nidow of foregoing)
Madeo III (1103-48)

Hubertinidi

(son Guglielno Lungaspada = Sibylla of Jerus.) Unberto III (1148-89)

(son Ranieri = Laria Komnene)

Corrado $(1190-92)=(1)$ Haria Angelina;

Ionuaso I (1189-1233)

\section{= (2) Isabella of Jerusalen}

Bonifacio I $(1192-1207)=(2)$ Harzaret of Hung. Madeo IV (1233-53)

Guglielmo YI (1207-25)

Bonifacio II (1225-53) == <--- Hargherita ---< (dtr of forezoing)

(sister klice = Henri ! de Lusizman)

Guglielmo YII il Gran Uarchese (1253-92)

(dtr Yolanda = Andronikos II

Pietro II (1253-88)

Palaiologos)

Filippo I (1288-85)

Madeo V il Grande

Giovanni $(1292-1305) \quad==<---$ Hargherita $---<($ dtr $) /(1285-1323)$

Edcardo il Liberale

Paleologhi (1323-29) 
Paleologhi

Edcardo il Liberale

Teodoro I (1305-1338) - (dtr) >-- Yolanda --> = finone il Pacifico

Giovanni II (1338-72)

Secondotto (1372-78)

Giovanni III (1378-81)

Teodoro II (1381-1418) (dtr

Sophia $=$ John VIII Palaiologos)

Giangiacono (1418-1445) == <---- Giovanna

(dtr Anadea = Jean II de Lusignan)

Giovanni IV (1445-1464)

Guglielno VIII (1464-83)

Bonifazio III (1483-94)

Guglielno IX (1494-1518)

(1329-43) [their son:]

madeo VI il Conte

Yerde (1343-83)

Madeo VII il Conte

Rosso (1383-91)

Bonifazio IV (1518-30)

Giansiorgio (1530-33)

- . - (Pine) - . -

de Lusignan)

Anadeo IX il Beato

(1465-72)

Filiberto I il Cacciatore (1472-82)

Carlo I il Guerriero (1482-90)

Carlo Giovanni hadeo (1490-96)

Filippo II Senzaterra (1496-97)

Filiberto II il Bello (1497-1504)

Carlo II il Buono (1504-53)

Enanuele Filiberto, Iesta di

Ferro (1553-80)

$$
\text { - Etc. - - }
$$

